International Journal of Innovation Management

Vol. 22, No. 2 (February 2018) 1850016 (23 pages)

(C) World Scientific Publishing Europe Ltd.

DOI: $10.1142 /$ S1363919618500160

\title{
CONTEXTUAL EFFECTS IN OPEN INNOVATION: A MULTI-COUNTRY COMPARISON
}

\author{
ANNA ARBUSSÃ $\tilde{*}^{*}$ and JOSEP LLACH \\ Department of Business Adminstration and Product Design \\ University of Girona, Campus Montilivi, 10071 Girona, Spain \\ *anna.arbussa@udg.edu
}

Published 15 June 2017

\begin{abstract}
This paper contributes to the understanding of the context dependency of open innovation. It does so by empirically analysing the relationship between innovation activities, firm characteristics and the degree of innovation openness of manufacturing companies in three European countries with varying degrees of technological development. Logistic regression analysis is used to study CIS data from Germany, Portugal and Bulgaria. In line with the contingency approach to open innovation, the results suggest that the appropriate open innovation strategy is context dependent, with similar practices and firm characteristics obtaining opposite relationship signs in different countries. Hence, it is important to take country idiosyncrasies into account when designing policies to promote open innovation.
\end{abstract}

Keywords: Open innovation; CIS; Context; country; product; process; European countries.

\section{Introduction}

This paper intends to shed light on how open innovation in companies can vary depending on the level of technological development of the country. It does so by investigating the relationship between innovation activities, firm characteristics and the degree of innovation openness of manufacturing firms in Germany, Portugal and Bulgaria.

The phenomenon of open innovation has gained wide acceptance since it was first 'labelled' by Chesbrough (2003) and defined as '... the use of purposive inflows and outflows of knowledge to accelerate internal innovation and to expand the markets for external use of innovation, respectively' (Chesbrough, 2006, p. 1). It is a concept that has been readily embraced by academics and practitioners alike. One of the reasons for its success is the fit of the paradigm in reflecting the changes the innovation environment has undergone over the last decade. Indeed, various phenomena related to contextual changes - globalisation and division of labour, 
changes in working patterns, improved market institutions for property rights, venture capital, technology standards and so on (Dahlander and Gann, 2010) suggest the appropriateness of a new paradigm for innovation activities.

In the open innovation paradigm, organisational boundaries are porous and firms interact with their environment (Gassmann, 2006; Gassmann et al., 2010; Chesbrough, 2003; Huizing, 2011). Hence, it seems plausible that different external contexts relate to variances in firms " innovation practices. In this regard, this paper examines the innovation practices of manufacturing firms in Germany, Portugal and Bulgaria, who according to the European Union Innovation Scoreboard (2008) have varying degrees of technological development: this index considers Germany to be an 'innovation leader', Portugal a 'moderate innovator' and Bulgaria a 'catching-up country'.

First, this paper studies the relationship between the introduction of new products and processes and firms " degree of openness in the development of the same. Second, it considers the role of innovation strategies, which we classify into innovations that are new to the market and innovations that are new to the firm, and it then relates them to the firm's degree of openness in the development of these new products and processes. Clearly, the consequences that being open may have in each case may be quite distinct (Huizing, 2011; Reed et al., 2012).

This paper considers a broad range of firms' innovation activities by including both product and process innovations. Whereas product innovations have traditionally been related to market demand (providing new products or entering new markets), process innovations are normally related to the supply side of the market (aimed, for instance, at lowering costs). Until now, most of the open innovation literature has focussed on product innovation (Huizing, 2011).

To our knowledge, this is among the first studies on open innovation to encompass large, medium and small manufacturing firms from European countries with different levels of technological development (see also, Cricelli et al., 2016, Bengtsson et al., 2015 and Revilla et al., 2016). Moreover, it is also one of the first articles to use large data sets to study open innovation in Portugal and Bulgaria. This paper complements previous empirical research on open innovation and external context, which up to now has focussed mainly on the effects of industry (Keupp and Gassman, 2006; Liechtenthaler and Ernst, 2009), technological aggressiveness (Poot et al., 2009; Reed et al., 2012), competitive intensity (Lichtenthaler, 2008; Sandulli et al., 2012) and appropriability conditions (West, 2006). Additional external factors studied in the literature are technological intensity and knowledge leveraging, among others (Gassmann, 2006).

The country effect of open innovation is important for policy design. In the European Union, innovation policies co-exist at several levels: European, national and regional (Balaz et al., 2005; García Manjón, 2010) and while efforts are 
Table 1. Description of countries by degree of openness in product and process innovations.

\begin{tabular}{|c|c|c|c|c|c|c|c|}
\hline & & \multicolumn{2}{|c|}{ Bulgaria } & \multicolumn{2}{|c|}{ Germany } & \multicolumn{2}{|c|}{ Portugal } \\
\hline & & $n$ & $\%$ & $n$ & $\%$ & $n$ & $\%$ \\
\hline \multirow[t]{2}{*}{ Mainly enterprise } & Product & 1297 & 79.8 & 1047 & 75.8 & 1142 & 77.0 \\
\hline & Process & 1189 & 72.1 & 652 & 55.9 & 1121 & 64.1 \\
\hline \multirow[t]{2}{*}{ In cooperation } & Product & 172 & 10.6 & 281 & 20.3 & 270 & 18.2 \\
\hline & Process & 201 & 12.2 & 391 & 33.5 & 479 & 27.4 \\
\hline \multirow[t]{2}{*}{ Mainly other enterprises } & Product & 156 & 9.6 & 53 & 3.8 & 71 & 4.8 \\
\hline & Process & 258 & 15.7 & 123 & 10.5 & 149 & 8.5 \\
\hline \multirow[t]{2}{*}{ Total } & Product & 1625 & 100 & 1381 & 100 & 1483 & 100 \\
\hline & Process & 1648 & 100 & 1166 & 100 & 1749 & 100 \\
\hline
\end{tabular}

expended to coordinate these policies, the Union also recognises the need to take countries' idiosyncrasies such as infrastructures, level of investment and general level of education and so on into account in the design of policies promoting innovation (European Commission, 2011; Izsak et al., 2015). Similarly, in the case of open innovation, various European Union initiatives that seek to promote open innovation state the need to take individual country characteristics into consideration (European Commission, 2016). This paper may also be of interest to managers of firms with operations in multiple countries with various levels of technological development.

The remainder of the paper is structured as follows. The Literature Review section presents an overview of the literature and puts forward the hypotheses that guided the research. This is followed by a Methodological section that discusses the chosen research method. The Results are presented next, followed by Discussion of Results Section in which the findings are discussed. Implications for theory and practice are proposed in the Conclusions section, in addition to the limitations of the study and suggestions for future research.

\section{Literature Review}

\section{The degree of openness}

More than a decade ago, Chesbrough (2003) proposed open innovation as a new paradigm, which rapidly gained the acceptance of scholars and was widely implemented by practitioners.

In contrast to the dichotomy model of closed versus open innovation proposed in some articles, a large part of the literature considers how open innovation can be adopted to different degrees (Dahlander and Gann, 2010; Gassmann and Enkel, 2004; Hochleitner et al., 2017; Laursen and Salter, 2006; Lazzarotti and Manzini, 2009; Verganti and Pisano, 2008). 
There have been different attempts to characterise the degree of openness. For instance, Laursen and Salter (2006) define the concepts of breadth (number of different search channels) and depth (intensity of use of sources of innovative ideas) of open innovation activities and Keupp and Gassmann (2009) identify four archetypes of firms, which are classified according to the breadth and depth of their open innovation. Verganti and Pisano (2008) propose a model that relates hierarchical organisational levels with degree of openness and Lazzarotti and Manzini (2009) introduce the number and type of partners and the type of phases of the innovation process that are open as measures of the firm's degree of openness. Moreover, Gassmann and Enkel (2004) consider inbound, outbound and coupled activities, whereas Dahlander and Gann (2010) use the dimensions of inbound versus outbound open innovation activities and pecuniary versus non-pecuniary interactions.

This paper adopts a measure of the firm's degree of openness that distinguishes between firms for which innovation remains essentially an internal matter and firms that have embraced the open innovation paradigm, a distinction based on the direct answers given by the firms' managers in the CIS questionnaire. Although this approach results in a dichotomic valuation, the phrasing of the questionnaire on which it is based acknowledges that the boundary between open and closed innovation is blurred and that the degree of openness is in fact a continuum. The limitations of this approach are discussed later in the paper.

While the positive implications of open innovation seem to prevail, its alleged benefits - such as accelerating internal innovation and expanding the markets for external use of innovation (Chesbrough, 2006) - have not gone unquestioned. Part of the literature has also highlighted the disadvantages that open innovation can have, such as more complex innovation processes that result in higher managerial costs, the 'not invented here' syndrome, unwanted spillovers and other effects that lower firms' competitive advantage (Cheng and Shiu, 2015; Lazzarotti and Manzini, 2009; Raasch et al., 2009; Reed et al., 2012; Van de Vrande et al., 2009; West, 2006).

Recognising both the benefits and costs of open innovation, the optimal degree of openness for a given firm would result from a balance between the positive and negative effects of open innovation in a given context that is characterised by internal and external factors (Reed et al., 2012; Sandulli et al., 2012; West and Gallagher, 2006). The context effects are discussed in the next sections.

\section{Context effects}

The context effects of open innovation have been studied in relation to several of firms' external and internal factors. In this study, we focus on the country effect as a contingency that can affect firms' optimal choices in terms of the degree of openness. 
Among the external context effects that have been studied, the most widely analysed is the effect of industry (Keupp and Gassmann, 2009; Lichtenthaler and Ernst, 2009). As a matter of fact, open innovation was initially proposed based on evidence from a handful of large high-tech companies (Chesbrough, 2006) and from there it extended to other sectors, which were not necessarily high-tech industries (Dahlander and Gann, 2010). Other context effects considered have been technological aggressiveness (Poot et al., 2009; Reed et al., 2012), technological intensity and knowledge leveraging (Gassmann, 2006), competitive intensity (Lichtenthaler, 2008; Sandulli et al., 2012) and the appropriability regime (West and Gallagher, 2006).

Country effects may encompass several of the context effects mentioned above. For instance, the appropriability regime varies with the type of knowledge (whether it can be protected by legal instruments and/or by strategic instruments, like time to market, secrecy and so on) in a given industry but also, in the case of multi-country studies, with how effective the enforcement of the rights on knowledge is in each country. Similarly, technological intensity and knowledge leveraging vary across industries (Gassmann, 2006) as well across countries with different levels of technological development (by constructing the European Union Innovation Scoreboard index used in this study).

In a review, Gassmann et al. (2010) pointed to the need for further research on the degree of globalisation of open innovation (the spatial perspective). These authors suggest that the uneven distribution of knowledge across territories may have hindered the shift in paradigm from closed to open innovation in less technologically developed economies. In this sense, it seems plausible that firms in more technologically developed countries where knowledge is more widespread may be able to benefit more from being open than their counterparts in less developed ones (Gassmann et al., 2010).

Geographically, the relevance of open innovation has been empirically shown for many firms in technologically developed economies, with most empirical work initially carried out with data on US firms, but later including large data studies from different European countries including the United Kingdom (Laursen and Salter, 2006), France (Simeth and Raffo, 2013), the Netherlands (Poot et al., 2009; Raymond et al., 2006), Denmark (Tranekjer and Knudsen, 2012), Spain (BargeGil, 2013), Belgium (Faems et al., 2010), Germany, Switzerland and Austria (Inauen and Schenker-Wicki, 2011), Italy, Finland and Sweden (Bengtsson et al., 2015). However, despite all this evidence, there are still few studies on open innovation in less technologically developed European economies. Moreover, some multi-country studies that include data from less technologically developed economies do not control for country effects (Cricelli et al., 2016). 
This paper characterises open innovation in European countries with different levels of technological development. The use of homogeneous CIS data allows for a comparison of open innovation across the three countries studied.

\section{Innovation activities}

Both product and process innovations are included in the analysis. Product innovations are traditionally related to market demand, through providing new products or entering new markets, whereas process innovations are normally related to the supply side of the market and are aimed at lowering costs or reducing production or delivery time (Martinez-Ros, 2000). The information on process innovations is normally less visible to other firms than the information on product innovations. Up to now, most open innovation articles have predominantly focussed on product innovations, with some exceptions (see for instance West and Gallagher, 2006). Including process innovations in our analysis contributes to bridging this gap. Given their different nature, one cannot assume a priori that the relationship between the openness of the firm and either type of innovation will be the same in a variety of contexts (Baldwin et al., 2002; Cohen and Klepper, 1996; Damanpour, 2010). Hence, this paper analyses product and process innovation data separately.

\section{Innovativeness}

This section begins by distinguishing between firms that introduced innovative products and/or processes into the market during the study period and firms that did not. We focus on the first group. According to Chesbrough (2006), openness can enhance a firms' ability to both innovate and to appropriate the benefits of innovation. Building upon this idea, it seems intuitive that there will be a positive relationship between the innovativeness of a particular firm and the degree of openness in the development of its innovations. Despite most of the empirical literature having found evidence to support this assumption (see, for instance, Bae and Chang, 2012; Barge-Gil, 2013; Nieto and Santamaría, 2007; Parida et al., 2012; Spithoven et al., 2010), some studies (for instance, Laursen and Salter, 2006) have found a negative relationship between open innovation activities and innovation outcomes. In line with the most frequent results, the following hypotheses are put forward:

\section{Hypotheses 1}

1a. Manufacturing firms that introduce more innovative products into the market are more likely to have a higher degree of openness in the development of their products. 
1b. Manufacturing firms that implement more innovative processes are more likely to have a higher degree of openness in the development of their processes.

\section{Innovation strategy}

Open innovation can contribute to innovation in general through easing the availability of information and its diffusion. The benefits and costs of these events might affect firms differently depending on their innovation strategies (Badawy, 2011; Gassmann, 2006; Keupp and Gassmann, 2009).

This paper distinguishes between firms that develop 'new-to-market' innovations and firms that only develop innovations that are 'new to the firm'. According to the OECD (2015), 'new-to-market' product innovation refers to the introduction of a new or significantly improved product into the firm's market before any other competitors (the product may have already been available in other markets).

Being first in a market can bring competitive advantage through patents obtained, being able to influence consumer preferences and being ahead of the competitors. On the other hand, imitators can save on research and development resources, as well as be able to compete more efficiently through improving the product launched by the market leader (Lieberman and Asaba, 2006). A broad range of articles from diverse approaches that study the incentives for invention versus imitation examine under which market conditions imitation can spur rather that dampen innovation. The degree of market competitiveness, the appropriation regime and the economic rents to be extracted from the consumer are among the relevant elements influencing the result.

While the increased flow of information and knowledge between firms that characterises open innovation eases imitation, the final effects of this increased flow of information on the introduction of innovations that are 'new- to-market' is unclear. Several studies have examined some of the arguments above in the context of open innovation (Cappelli et al., 2014; Cheng and Shiu, 2015; Hochleitner et al., 2017; Reed et al., 2012; Sandulli et al., 2012).

Cappelli et al. (2014) find that in an open innovation context some spillovers ease imitation while others enhance innovation. Cheng and Shui (2015) find that inbound open innovation activities (which are the ones mostly captured by CIS data) enhance radical innovation performance but hinder incremental innovation performance. In a recent paper, Hochleitner et al. (2017) distinguish between product innovators (in the sense of inventors or world-first innovators) and imitators and find that open innovation activities can be advantageous for both world-first innovators and imitators. The paper finds that open innovation can be advantageous not only for imitative innovation, but also for introducing world-first innovations. On the other hand, Reed et al. (2012) explore how open innovation 
may affect a firm with differentiation-based competitive advantage. The paper finds that economic rents from property rights (which can be positively related to 'new to market' products) can be lost in an open innovation context, while the rents from experience-curve effects, differentiation, distribution and switching costs are not.

While the recent evidence on the effects of open innovation in the development of 'new to market' products is mixed, we will favour the view that open innovation helps firms to create and commercialise innovations (West et al., 2014). Accordingly, we put forward the following hypotheses for both new-to-market products and process innovations:

\section{Hypotheses 2}

2a. Manufacturing firms that introduce more innovative products that are 'newto-market' are more likely to have higher degree of openness in the development of their products.

2b. Manufacturing firms that implement more innovative processes that are 'newto-market' are more likely to have a higher degree of openness in the development of their processes.

\section{Methodology}

\section{Data}

The data used for this study comes from the Community Innovation Survey (CIS), which is a harmonised survey in 22 European countries. This paper uses data from the CIS 2008 edition, which collected information about product and process innovation, organisational and marketing innovation and other key variables for the three-year period 2006-2008.

Three countries were selected to test the above hypotheses. The criteria for selecting the countries were (i) availability of data and (ii) country differentiation. We excluded the countries which were missing some of the variables used in this study and, because innovation activity differs widely across countries and economic sectors (Parvan, 2009), we chose to analyse countries with different levels of innovation development. We based our selection on 'The EU Summary Innovation Index' (European Union, 2008), which includes Germany (with an 'innovation index well above the EU-27 average') in the group of 'innovation leaders', Portugal (with an innovation index 'below that of the EU average') in the group of 'moderate innovators and Bulgaria (with index scores 'significantly below the EU27 average, but moving towards the average over time') in the fourth quartile of countries that are 'catching up'. 


\section{Measures}

\section{Dependent variable: Degree of openness}

There is no consensus in the literature on measuring the degree of openness of a firm. Indeed, various reviews (see for instance West et al., 2014) suggest the need for further research on this aspect.

The surge in empirical studies on open innovation using large data sets has brought about new 'proxies' for measuring the degree of openness of a firm including the range ('breadth') and intensity ('depth') of a firm's open innovation practices (for instance, Laursen and Salter, 2004; Laursen and Salter, 2006; Cruz-González et al., 2015; Keupp and Gassmann, 2009, the use of external sources and collaborations (for instance, Faems et al., 2010; Parida et al., 2012; Van de Vrande et al., 2009) and traces of patent data (for instance, Kim et al., 2016) to learn about firms' knowledge flows. This paper chooses to follow BargeGil $(2010,2013)$ and uses the answers to question 2.2 of the questionnaire for product (good or service) innovation and to question 3.2. for process innovation. In both cases the question is, 'Who developed these product/process innovations?' and there are three possible answers: (i) 'mainly your enterprise or enterprise group'; (ii) 'mainly your enterprise together with other enterprises or institutions' and (iii) 'mainly other enterprises or institutions'. Only one answer is permitted.

To test our hypotheses, we have transformed the three ordinal degrees of openness into a dichotomous variable where 0 means 'closed innovation' and 1 means 'some degree of openness'. In our view, this variable captures the concept of 'openness' more accurately than other proxies. Table 1 presents the descriptive analysis of the degree of openness by country with regards to the selected proxy. For both product and process innovation, the results show that the Bulgarian manufacturing firms are the most closed (79.8\% and $72.1 \%$, respectively). On the other hand, if we take 'some degree of openness' (by amalgamating the 'in cooperation' and 'mainly other enterprises' answers into a single category) into consideration, it can be observed that the German manufacturing firms are the most open for both product and process innovation $(24.1 \%$ and $44 \%$, respectively).

\section{Independent variables: product/process innovations and new to the market}

To account for innovativeness, this paper uses the answers to question 2.1, which asked 'During the three years 2006-2008, did your enterprise introduce?'. Two product innovation typology options were offered: 'new or significantly improved goods' and 'new or significantly improved services'. With regards to process innovation, this article uses the answers to question 3.2, which asked 'During the 
Table 2. Description of countries by product and process innovation typology.

\begin{tabular}{|c|c|c|c|c|c|c|c|}
\hline & & \multicolumn{2}{|c|}{ Bulgaria } & \multicolumn{2}{|c|}{ Germany } & \multicolumn{2}{|c|}{ Portugal } \\
\hline & & $N$ & $\%$ & $N$ & $\%$ & $n$ & $\%$ \\
\hline \multicolumn{8}{|l|}{ Product innovation: } \\
\hline \multirow[t]{3}{*}{ New or significantly improved goods* } & No & 7553 & 84.5 & 1527 & 54.1 & 2319 & 63.0 \\
\hline & Yes & 1389 & 15.5 & 1297 & 45.9 & 1362 & 37.0 \\
\hline & Total & 8942 & 100 & 2824 & 100 & 3681 & 100 \\
\hline \multirow[t]{3}{*}{ New or significantly improved services } & No & 8568 & 95.8 & 2538 & 90.0 & 2908 & 79.0 \\
\hline & Yes & 374 & 4.2 & 282 & 10.0 & 773 & 21.0 \\
\hline & Total & 8942 & 100 & 2820 & 100 & 3681 & 100 \\
\hline \multicolumn{8}{|l|}{ Process innovation: } \\
\hline \multirow{3}{*}{$\begin{array}{l}\text { New or significantly improved methods } \\
\text { of manufacturing or producing } \\
\text { goods or services }\end{array}$} & No & 7645 & 85.5 & 1916 & 65.5 & 2256 & 61.3 \\
\hline & Yes & 1297 & 14.5 & 1010 & 34.5 & 1425 & 38.7 \\
\hline & Total & 8942 & 100 & 2926 & 100 & 3681 & 100 \\
\hline \multirow{3}{*}{$\begin{array}{l}\text { New or significantly improved logistics, } \\
\text { delivery or distribution methods for } \\
\text { your inputs, goods or services }\end{array}$} & No & 8703 & 97.3 & 2494 & 85.2 & 3001 & 81.5 \\
\hline & Yes & 239 & 2.7 & 432 & 14.8 & 680 & 18.5 \\
\hline & Total & 8942 & 100 & 2926 & 100 & 3681 & 100 \\
\hline \multirow{3}{*}{$\begin{array}{l}\text { New or significantly improved } \\
\text { supporting activities for your } \\
\text { processes, such as maintenance } \\
\text { systems or operations for } \\
\text { purchasing, accounting or } \\
\text { computing }\end{array}$} & No & 8479 & 94.8 & 2389 & 81.6 & 2523 & 68.5 \\
\hline & Yes & 462 & 5.2 & 537 & 18.4 & 1158 & 31.5 \\
\hline & Total & 8941 & 100 & 2926 & 100 & 3681 & 100 \\
\hline
\end{tabular}

Note: *Exclude the simple resale of new goods purchased from other enterprises and changes of a solely aesthetic nature.

three years 2006-2008, did your enterprise introduce...?'. In this case, three different process innovation typologies were offered: improved methods of manufacturing or producing goods or services; improved logistics, delivery or distribution methods for your inputs, goods or services; and improved supporting activities for your processes, such as maintenance systems or operations for purchasing, accounting or computing.

Table 2 presents the frequencies and percentages of the number of product and process innovations introduced by country. With regards to product innovation, it can be observed that the introduction of 'new or significantly improved goods' is 
much more frequent than the introduction of 'new or significantly improved services'. By country, Germany introduces more 'new or significantly improved goods' and Portugal introduces more 'new or significantly improved services.'

Similarly, the introduction of one type of process innovation (improved methods of manufacturing or producing goods or services) is also much more frequent than the rest. Portugal is the country with the highest introduction of process innovations of any type, with Germany following close behind.

The measure for 'new- to-market' comes from two CIS questions. With regards to product innovation, this article uses the answers to question 2.3, which asked 'Were any of your product innovations during the three years 2006-2008 within the category new to the market?' With regards to process innovation, three options were offered to answer question 3.3, which asked 'Were any of your process innovations introduced between 2006 and 2008 new to your market?': 'Yes', 'No' and 'Do not know'. Table 3 presents the frequencies and percentages of product and process innovations introduced that were new to the market during the period 2006-2008.

\section{Control variables: size and belonging to a group}

The CIS questionnaire provides the opportunity to control for the potential impact of some firm-specific characteristics on the degree of openness. Two control variables, size and belonging to a group, were introduced into the model. To measure size, this paper uses the answers to question 11.2, which asked 'What was your enterprise's total number of employees in 2006 and 2008?' For the purposes of this study, only the data from 2008 was used. To assess whether the firm

Table 3. CIS description of countries by $\%$ of product and $\%$ of process innovations which are new to the market.

\begin{tabular}{|c|c|c|c|c|c|c|c|}
\hline & & \multicolumn{2}{|c|}{ Bulgaria } & \multicolumn{2}{|c|}{ Germany } & \multicolumn{2}{|c|}{ Portugal } \\
\hline & & $N$ & $\%$ & $n$ & $\%$ & $N$ & $\%$ \\
\hline \multicolumn{8}{|l|}{ Product innovation: } \\
\hline \multirow[t]{3}{*}{ New to the market* } & No & 964 & 59.3 & 2139 & 67.6 & 645 & 43.5 \\
\hline & Yes & 661 & 40.7 & 1026 & 32.4 & 838 & 56.5 \\
\hline & Total & 1625 & 100 & 3165 & 100 & 1483 & 100 \\
\hline \multicolumn{8}{|l|}{ Process innovation: } \\
\hline & No & 1127 & 82.1 & 2185 & 88.3 & 694 & 51.9 \\
\hline & Yes & 246 & 17.9 & 290 & 11.7 & 644 & 48.1 \\
\hline & Don't know & 0 & 0.0 & 0 & 0.0 & 0 & 0.0 \\
\hline & Total & 1373 & 100 & 2475 & 100 & 1338 & 100 \\
\hline
\end{tabular}

Note: *Your enterprise introduced a new or significantly improved good or service into your market before your competitors (it may have already been available in other markets). 
Table 4. Description of countries by control variable (only manufacturing firms).

\begin{tabular}{|c|c|c|c|c|c|c|c|}
\hline & & \multicolumn{2}{|c|}{ Bulgaria } & \multicolumn{2}{|c|}{ Germany } & \multicolumn{2}{|c|}{ Portugal } \\
\hline & & $n$ & $\%$ & $N$ & $N$ & $\%$ & $N$ \\
\hline \multicolumn{8}{|l|}{ Size: } \\
\hline \multirow[t]{4}{*}{$\begin{array}{l}\text { What was your } \\
\text { enterprise's total } \\
\text { number of employees } \\
\text { in } 2006 \text { and } 2008\end{array}$} & $<50$ employees & 6456 & 72.2 & 1235 & 37.7 & 2368 & 64.3 \\
\hline & 50-249 empl. & 2142 & 24.0 & 1135 & 34.7 & 1071 & 29.1 \\
\hline & $>250$ empl. & 344 & 3.8 & 905 & 27.6 & 242 & 6.6 \\
\hline & Total & 8942 & 100 & 3275 & 100 & 3681 & 100 \\
\hline \multirow{3}{*}{$\begin{array}{l}\text { Belonging to a group*: } \\
\text { In 2008, was your } \\
\text { enterprise part of an } \\
\text { enterprise group? }\end{array}$} & No & 8296 & 92.8 & 1828 & 55.8 & 2995 & 81.4 \\
\hline & Yes & 646 & 7.2 & 1447 & 44.2 & 686 & 18.6 \\
\hline & Total & 8942 & 100 & 3275 & 100 & 3681 & 100 \\
\hline
\end{tabular}

Note: *A group consists of two or more legally defined enterprises under common ownership. Each enterprise in the group can serve different markets, as with national or regional subsidiaries, or serve different product markets. The head office is also part of an enterprise group.

belongs to a group, this paper uses the answers to question 1.1, which asked 'In 2008, was your enterprise part of an enterprise group?' The descriptive analysis is shown in Table 4.

In terms of size, Bulgaria and Portugal are similar in the sense of having a large percentage of small firms, while Germany has a more balanced percentage of firms across the three categories.

Similar patterns are observed for 'belonging to a group'. Bulgaria and Portugal are alike with over $80 \%$ of their firms not belonging to a group, whereas Germany has a more balanced sample of independent firms and firms belonging to a group.

\section{Results}

Logistic regression analysis is used to contrast the hypotheses previously raised. Mention et al. (2013) explain how this is an often-used method to investigate the relationship between discrete responses and a set of explanatory variables. The same authors also list various references that discuss the validity of the technique (e.g., Agresti, 1990; Collet, 1991; Cox and Snell, 1989; Hosmer and Lemeshow, 2000; Stokes et al., 2000). 
All the variables in the full models are treated as dichotomous variables, except for the control variable SIZE, which is transformed from an ordinal of three categories to a dummy variable ( $0:<50$ employees; $1:>=50$ employees), as shown in Table 4.

Table 5 summarises the definitions and measurements of the variables of our models. The full models are as follows:

- Model $A_{n}:$ Logit $\left(O P E N \_P R O D\right)=b 0+b 1 * I N P D G D+b 2 * I N P D S V+b 3 *$ $N E W M K T+b 4 * S I Z E+b 5 * G P$.

Table 5. Definition and measurement of variables.

\begin{tabular}{|c|c|}
\hline Variable & Definition and measurement \\
\hline \multicolumn{2}{|c|}{ Dependent variables } \\
\hline OPEN_PROD & $\begin{array}{l}1 \text { if the firm has some degree of openness in product innovation } \\
0 \text { otherwise }\end{array}$ \\
\hline OPEN_PROC & $\begin{array}{l}1 \text { if the firm has some degree of openness in process innovation } \\
0 \text { otherwise }\end{array}$ \\
\hline \multicolumn{2}{|c|}{ Independent variables } \\
\hline INPDGD & $\begin{array}{l}1 \text { if the firm has introduced new or significantly improved goods } \\
0 \text { otherwise }\end{array}$ \\
\hline INPDSV & $\begin{array}{l}1 \text { if the firm has introduced new or significantly improved services } \\
0 \text { otherwise }\end{array}$ \\
\hline NEWMKT & $\begin{array}{l}1 \text { if the firm has introduced new or significantly product innovations that are new } \\
\text { to the market } \\
0 \text { otherwise }\end{array}$ \\
\hline INPSPD & $\begin{array}{l}1 \text { if the firm has introduced new or significantly improved methods of } \\
\text { manufacturing or producing goods or services } \\
0 \text { otherwise }\end{array}$ \\
\hline
\end{tabular}

INPSLG $\quad 1$ if the firm has introduced new or significantly improved logistics, delivery or distribution methods for inputs, goods or services

0 otherwise

NPSSU $\quad 1$ if the firm has introduced new or significantly improved supporting activities in its processes, such as maintenance systems or operations for purchasing, accounting or computing

0 otherwise

INPSNM 1 if a firm has introduced new or significantly process innovations that are new to the market

0 otherwise

Control variables

SIZE $\quad 1$ if a firm has more than 50 employees

0 otherwise

GP $\quad 1$ if a firm belongs to a group

0 otherwise 
- Model $B_{n}:$ Logit $\left(O P E N \_P R O C\right)=b 0+b 1 * I N P S P D+b 2 * I N P S L G+b 3 *$ $I N P S S U+b 4 * I N P S N M+b 5 * S I Z E+b 6 * G P$.

Table 6 presents the results of the six regressions models performed. For each country, Models A and B are contrasted by logistic regression analysis and the results obtained for each country are now discussed.

In the case of Germany, similar results are obtained for the Models $A_{1}$ and $B_{1}$. In $A_{1}$ two independent variables are statistically significant with a negative sign, INPDGD and NEWMAKT. In $\mathrm{B}_{1}$ there are also two significant independent variables, again with a negative sign, INPSPD and INPSNM. These results seem to indicate that the firms that are most innovative and also introduce more innovations that are new to the market are the ones with a lower degree of openness. Some differences between product and process innovations are observed in the control variables: SIZE is the only significant variable and is negative in the case

Table 6. Logit regression models.

\begin{tabular}{|c|c|c|c|c|c|c|}
\hline \multirow{4}{*}{$\begin{array}{l}\text { Dependent variable } \\
\text { Model } \\
\text { Independent variable }\end{array}$} & \multicolumn{2}{|c|}{ Germany } & \multicolumn{2}{|c|}{ Portugal } & \multicolumn{2}{|c|}{ Bulgaria } \\
\hline & OPEN_PROD & OPEN_PROC & OPEN_PROD & OPEN_PROC & OPEN_PROD & OPEN_PROC \\
\hline & $\mathrm{A}_{1}$ & $\mathrm{~B}_{1}$ & $\mathrm{~A}_{2}$ & $\mathrm{~B}_{2}$ & $\mathrm{~A}_{3}$ & $\mathrm{~B}_{3}$ \\
\hline & & & & & & \\
\hline \multirow[t]{2}{*}{ INPDGD } & $-0.871 * * *$ & & $-0.393 * * *$ & & 0.358 & \\
\hline & $(0.28)$ & & $(0.12)$ & & $(0.24)$ & \\
\hline \multirow[t]{2}{*}{ INPDSV } & 0.001 & & $0.448 * * *$ & & $0.844 * * *$ & \\
\hline & $(0.22)$ & & $(0.08)$ & & $(0.19)$ & \\
\hline \multirow[t]{2}{*}{ NEWMKT } & $-0.368 * * *$ & & $-0.248^{* * *}$ & & $0.700 * * *$ & \\
\hline & $(0.13)$ & & $(0.07)$ & & $(0.13)$ & \\
\hline \multirow[t]{2}{*}{ INPSPD } & & $-0.487 * * *$ & & $-0.310^{* *}$ & & -0.064 \\
\hline & & $(0.22)$ & & $(0.09)$ & & $(0.21)$ \\
\hline \multirow[t]{2}{*}{ INPSLG } & & -0.257 & & $-0.130^{*}$ & & -0.028 \\
\hline & & $(0.18)$ & & $(0.07)$ & & $(0.18)$ \\
\hline \multirow[t]{2}{*}{ INPSSU } & & 0.210 & & $1.049 * * *$ & & $-0.336^{*}$ \\
\hline & & $(0.17)$ & & $(0.08)$ & & $(0.19)$ \\
\hline \multirow[t]{2}{*}{ INPSNM } & & $-0.814 * * *$ & & $-0.174 * *$ & & $0.387 * *$ \\
\hline & & $(0.16)$ & & $(0.07)$ & & $(0.15)$ \\
\hline \multicolumn{7}{|l|}{ Control variables } \\
\hline \multirow[t]{2}{*}{ SIZE } & $-0.597 * * *$ & 0.285 & -0.090 & $0.566 * * *$ & 0.062 & $0.395 * * *$ \\
\hline & $(0.15)$ & $(0.19)$ & $(0.09)$ & $(0.08)$ & $(0.13)$ & $(0.12)$ \\
\hline \multirow[t]{2}{*}{ GP } & -0.142 & $-0.502 * * *$ & $-0.280 * *$ & 0.063 & 0.082 & -0.048 \\
\hline & $(0.15)$ & $(0.17)$ & $(0.12)$ & $(0.10)$ & $(0.17)$ & $(0.17)$ \\
\hline Log likelihood & 1327.396 & 924.628 & 4258.232 & 4390.351 & 1577.618 & 1596.175 \\
\hline Nagelkerke $\mathrm{R}^{2}$ & 0.062 & 0.096 & 0.032 & 0.095 & 0.054 & 0.022 \\
\hline$N$ & 1282 & 707 & 1483 & 1338 & 1625 & 1372 \\
\hline
\end{tabular}

Notes: First category as a reference in all the dependent variables.

Robust standard errors are reported in brackets under the logistic regression coefficients.

$* * * p<0.01 ; * * p<0.05 ; * p<0.1$. 
of product innovation and GP is only significant and negative in the case of process innovation.

The results obtained for the two Portugal models are similar to those of the Germany model, with some differences. First, although in Model $\mathrm{A}_{2}$ the two countries have the same significant variables, the coefficients are lower. Also, the variables INPSPD and INPSNM have significant coefficients with the same sign as Model $\mathrm{B}_{1}$, but they have lower coefficients. Moreover, in Model $\mathrm{B}_{2}$ INPSLG and INPSSU are significant with a negative and positive sign, respectively. Finally, there are also differences in the control variables of Models $A_{2}$ and $B_{2}$ In $A_{2}$ only GP is significant with a negative sign and in $B_{2}$ only SIZE is significant with a positive sign.

In contrast with the Germany and Portugal models, most of the significant variables for Bulgaria have positive coefficients (INPDSV and NEWMKT in Model $\mathrm{A}_{3}$ and INPSNM in Model $\mathrm{B}_{3}$ ). Only the variable INPSSU has a negative sign and then with a low significance $(p<0.1)$. These results would suggest that the more innovative the Bulgarian manufacturing firms are and the greater the number of these innovations that are new to the market, the higher the probability of the firms being more 'open'. In the case of Bulgaria, the variable SIZE is significant only in model $\mathrm{B}_{3}$. GP is not significant in either model.

\section{Discussion of Results}

The results of our regression analysis show the validity of the contextual approach for both product and process innovations, for which this article runs separate regressions. With regards to product innovations, the sign of the relationship between the degree of innovativeness of a firm and the degree of openness of the economy is significant and negative for Germany and Portugal in the case of goods and significant and positive in Bulgaria in the case of services. Hence, Hypothesis 1a is partially accepted for Bulgaria and rejected for Germany and Portugal. Therefore, there are clear country divergences.

In the case of Hypothesis $1 \mathrm{~b}$, the relationship is significant and negative for Germany and Portugal in the case of improved methods of manufacturing. In the case of improved logistics, delivery or distribution methods, the relationship is significant but negative for Portugal. Finally, in the case of supporting activities, which was found to be the less extended process innovation, it is positive and significant for Portugal and negative and significant for Bulgaria. Hence, Hypothesis $1 \mathrm{~b}$ is mostly rejected. Here as well, the results differ between countries.

In the case of Hypothesis 2a, the results for Germany and Portugal are significant but negative and significant and positive for Bulgaria. Hence, Hypothesis $2 \mathrm{a}$ 
is partially accepted. The significance and signs of the relationships tested in Hypothesis $2 \mathrm{~b}$ are the same as for Hypothesis 2a. Again, there are sign divergences between countries.

These results suggest that the relationship between the choice of the degree of openness and the innovativeness and innovation strategy of firms may well depend on the level of technological development of the environment in which the firm operates. On the other hand, there seems to be no clear pattern in the relationship between either the size of a firm and whether this firm belongs to a group and its degree of openness.

\section{Conclusions}

This paper constitutes a first approach to a European cross-country comparison of open innovation, a surprisingly little-explored field given the surge of articles on this topic in recent years. Moreover, the proliferation of studies that have found empirical evidence of open innovation practices in firms in Western economies has not been accompanied by a similar abundance of research evidence of the same in firms in less developed economies. Recent reviews have stressed the need to take context dependencies into consideration. In this regard, this paper takes the fact that the degree of technological development of an economy is a relevant factor into consideration.

First, the paper examines the relation between the degree of openness of a firm and its innovativeness in terms of the number of positive answers to the introduction of product and the implementation of process innovations. Second, it relates a firm's degree of openness with its innovation strategy. It also controls for the effect of size and belonging to a group.

With regards to the relationship between innovativeness and the degree of openness of firms, the signs of the regressions confirm that there are differences between the three countries: the sign is negative in the cases of Germany and Portugal and positive in the case of Bulgaria.

With regards to innovation strategies, the results of the analysis show that there are country differences in the relationship between introducing products or processes that are 'new-to-market' and the degree of openness of firms.

The results obtained suggest that the country contingency factor should be taken into consideration in multi-country studies covering countries with different levels of technological development.

This approach at a multi-national level may uncover other external contingency effects that the literature has examined at a national and/or industry level (appropriability regime, technological intensity and so on). For instance, in 
choosing the degree of openness, factors like market structure or the potential rents from customers might be more relevant than the availability of knowledge, which is more pertinent to developed economies.

The results of this study are relevant for academics as they show the need to control for country characteristics in the study of open innovation. Managers may also like to take this paper into account, as it shows how different innovation strategies can have different consequences depending on the level of technological development of the country in question. Finally, this study is potentially interesting for policy makers as it stresses the need to at least partially customise the initiatives aimed at promoting open innovation.

The limitations of this study are two-fold. The first obvious limitation is that the validity of its results applies only to the set of data from the countries studied; problems with the comparability of the data (responses to some questions were not available for all countries and/or were tabulated differently) prevented us from including more countries in the analysis. In this respect, further studies that compare open innovation across countries with differing degrees of technological development are needed. Second, it may be interesting to include more years in the study to learn about the evolution of the openness of innovation strategies. Again, in this regard we encountered some difficulties, which were related to changes in the questionnaire over the intended period of study.

More research is needed using data that allows for the control of more external contingency factors to be able to compare the results with those of this paper. Additionally, it may be interesting to compare our approach to measuring the degree of openness of a firm's innovation activities with previously published approaches like breadth and depth (i.e., Laursen and Salter, 2004; Laursen and Salter, 2006; Cruz-González et al., 2015; Keupp and Gassmann, 2009), while controlling for country dependency. These tests may contribute to validating the various measures, which could then be used to analyse the openness of innovation in countries with data missing for some variables. 


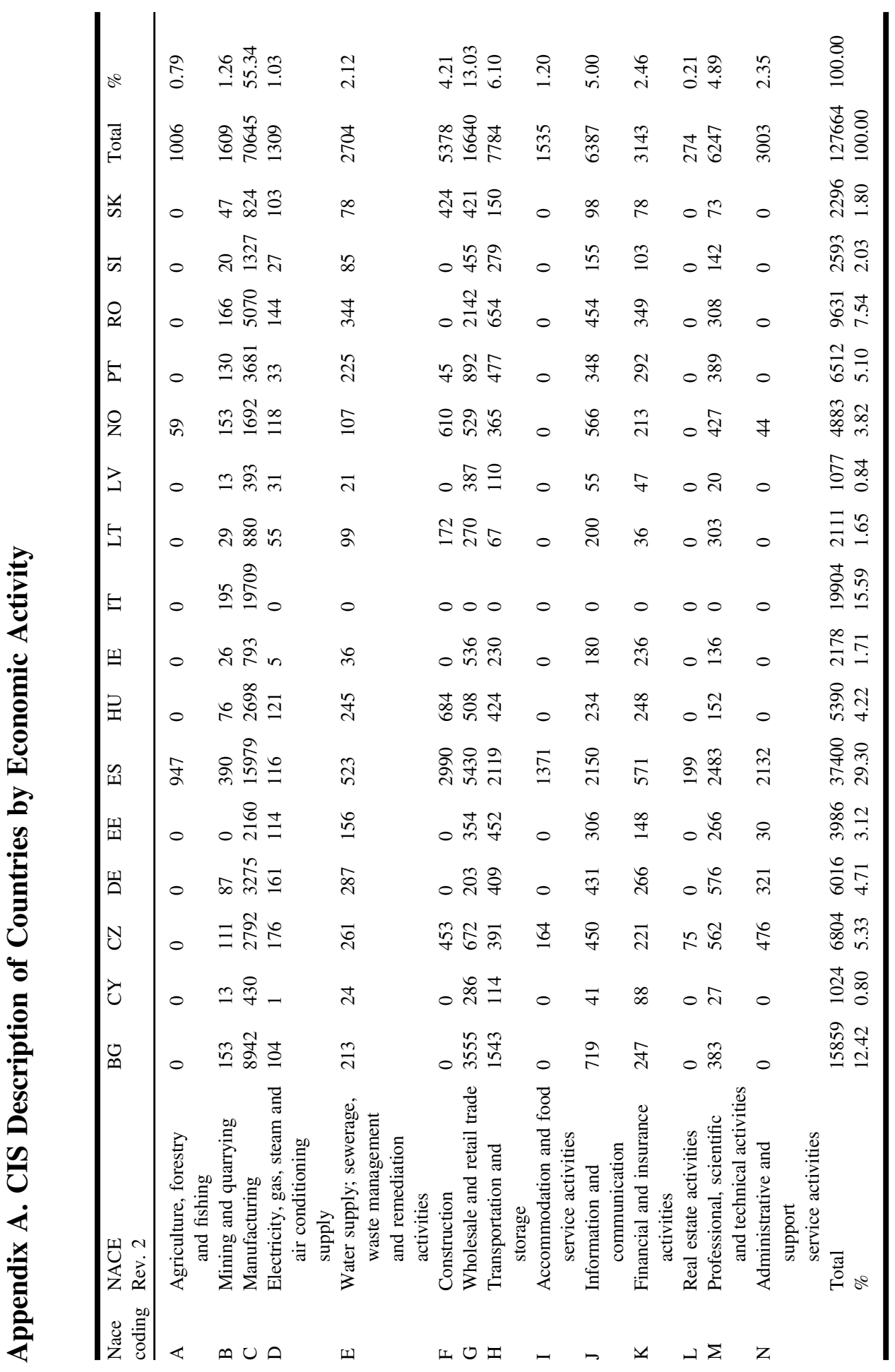




\section{References}

Agresti, A (1990). Categorical Data Analysis, New York, NY: John Wiley \& Sons, Inc. Badawy, M (2011). Is open innovation a field of study or a communication barrier to theory development? A perspective. Technovation, 31(1), 65-67.

Bae, Y and H Chang (2012). Efficiency and effectiveness between open and closed innovation: Empirical evidence in South Korean manufacturers. Technology Analysis \& Strategic Management, 24(10), 967-980.

Balaz, V, T Kluvankova and S Zajac (2005). Conceptual Economic Issues of Regional Innovations, Institute for Forecasting. Bratislava: Slovak Academy of Science.

Baldwin, J, P Hanel and D Sabourin (2002). Determinants of innovative activity in Canadian manufacturing firms. In: Innovation and Firm Performance. A Kleinknecht and P Mohnen (Eds.), pp. 86-111, New York: Palgrave.

Barge-Gil, A (2010). Open, semi-open and closed innovators: Towards an explanation of degree of openness. Industry and Innovation, 17(6), 577-607.

Barge-Gil, A (2013). Open strategies and innovation performance. Industry and Innovation 20(7), 585-610.

Bengtsson L, N Lakemond, V Lazzarotti, R Manzini, L Pellegrini and F Tell (2015). Open to a select few? Matching partners and knowledge content for open innovation performance. Creativity and Innovation Management, 24(1), 72-86.

Cappelli, RD, D Czarnitzki and K Kraft (2014). Sources of spillovers for imitation and innovation. Research Policy, 42(1), 115-120.

Chandler, A (1990). Scale and Scope: The Dynamics of Industrial Capitalism, Cambridge, MA: Harvard University Press.

Cheng, C and E Shui (2015). The inconvenient truth of the relationship between open innovation activities and innovation performance. Management Decision 53(3), 625-647.

Chesbrough, H (2003). Open Innovation: The New Imperative for Creating and Profiting from Technology, Cambridge, MA: Harvard University Press.

Chesbrough, H (2006). Open innovation: A new paradigm for understanding industrial innovation. In: Open Innovation: Researching a New Paradigm, H Chesbrough, W Vanheverbeke and J West (Eds.), pp. 1-12, Oxford: Oxford University Press.

Chesbrough, $\mathrm{H}$ and AK Crowther (2006). Beyond high tech: Early adopters of open innovation in other industries. $R \& D$ Management, 36(3), 229-236.

Christensen, JF, MH Olesen and JS Kjaer (2005). The industrial dynamics of open innovation-evidence from the transformation of consumer electronics. Research Policy 34(10), 1533-1549.

Cohen, W and S Klepper (1996). Firm size and the nature of innovation within industries: The case of process and product R\&D. Review of Economics and Statistics, 78(2), 232-243.

Collet, D (1991). Modeling Binary Data. London: Chapman and Hall.

Cox, DR and EJ Snell (1989). The Analysis of Binary Data. London: Chapman and Hall. 
Cricelli, L, M Greco and M Grimaldi (2016). Assessing the open innovation trends by means of the Eurostat Community Innovation survey. International Journal of Innovation Management, 20(3), DOI:10.1142/S1363919616500390.

Cruz-González, J, P López-Sáez, JE Navas-López and M Delgado-Verde (2015). Open search strategies and firm performance: The different moderating role of technological environmental dynamism. Technovation, 35, 32-45.

Dahlander, L and D Gann (2010). How open is innovation. Research Policy, 39(6), 699-709.

Damanpour, F (2010). An integration of research findings of effects of firm size and market competition on product and process innovations. British Journal of Management, 21(4), 996-1010.

European Commission (2011). Innovation Union Scoreboard 2010, European Commission, Brussels.

European Commission (2016). Open Innovation 2.0, European Commission, Luxembourg. European Union (2008). European Union Scoreboard. Summary Innovation Index, European Commission, Brussels.

Faems, D, M De Visser, P Andries and B Van Looy (2010). Technology alliance portfolios and financial performance: Value-enhancing and cost-increasing effects of open innovation. Journal of Product Innovation Management, 27(6), 785-796.

García Manjón, J (2010). A proposal of indicators and policy framework for innovation benchmark in Europe. Journal of Technology Management \& Innovation, 5(2), 13-23.

Gassmann, O (2006). Opening up the innovation process: Towards an agenda. $R \& D$ Management, 36(3), 223-228.

Gassmann, O and E Enkel (2004). Towards a theory of open innovation: Three core process archetypes. In R\&D Management Conf. Lisbon.

Gassmann, O, E Enkel and H Chesbrough (2010). The future of open innovation. $R \& D$ Management, 40(3), 213-221.

Hochleitner, FP, A Arbussà and G Coenders (2017). Inbound open innovation in SMEs: indicators, non-financial outcomes and entry-timing, Technology Analysis \& Strategic Management, 29(2), 204-218.

Hosmer, DW Jr. and S Lemeshow (2000). Applied Logistic Regression. New York: John Wiley \& Sons, Inc.

Huizing, E (2011). Open innovation: State of the art and future perspectives. Technovation, 31, 2-9.

Inauen, M and A Schenker-Wicki (2011). The impact of outside-in open innovation on innovation performance. European Journal of Innovation Management, 14(4), 496-520.

Izsak, K, P Markianidou and S Radosevic (2015). Convergence of national innovation policy mixes in Europe - Has it gone too far? An analysis of research and innovation policy measures in the period 2004-12. Journal of Common Market Studies, 53(4), 786-802.

Keupp, M and O Gassmann (2009). Determinants and archetype users of open innovation. R\&D Management, 39(4), 331-341. 
Kim, S, H Kim and E Kim (2016). How knowledge flow affects Korean ICT manufacturing firm performance: A focus on open innovation strategy. Technology Analysis \& Strategic Management, 28(10), 1167-1181.

Kirschbaum, R (2005). Open innovation in practice. Research Technology Management, 48(4), 24-28.

Lamoreaux, N, D Raff and P Temin (1999). Learning by Doing in Markets, Firms, and Countries, Chicago, IL: University of Chicago Press.

Laursen, K and A Salter (2004). Searching high and low: What type of firms use universities as a source of innovation? Research Policy, 33(8), 1201-1215.

Laursen, K and A Salter (2006). Open for innovation: The role of openness in explaining innovation performance among U.K. manufacturing firms. Strategic Management Journal, 27(2), 131-150.

Lazzarotti, V and R Manzini (2009). Different modes of open innovation: A theoretical framework and an empirical study. International Journal of Innovation Management, 13(04), 615-636.

Lazzarotti, V, R Manzini and L Pellegrini (2011). Firm-specific factors and the openness degree: A survey of Italian firms. European Journal of Innovation Management, 14(4), 412-434.

Lee, S, G Park, B Yoon and J Park (2010). Open innovation in SMEs - An intermediated network model. Research Policy, 39(2), 290-300.

Lerner, J (2000). 150 years of patent protection. Working paper N.7478, National Bureau of Economic Research, Cambridge, MA.

Lichtenthaler, U (2008). Open innovation in practice: An analysis of strategic approaches to technology transactions. IEEE Transactions on Engineering Management, 55(1), 148-157.

Lichtenthaler, U and H Ernst (2009). Opening up the innovation process: The role of technology aggressiveness. $R \& D$ Management, 39(1), 38-54.

Lieberman, M and S Asaba (2006). Why do firms imitate each other? Academy of Management Review, 31(2), 366-385.

Manzini, R, V Lazzarotti and L Pellegrini (2016). How to Remain as Closed as Possible in the Open Innovation Era: The Case of Lindt \& Sprüngli. Long Range Planning. Doi: 10.1016/j.lrp.2015.12.011.

Martinez-Ros, E (2000). Explaining the decisions to carry out product and processes innovations: The Spanish case. Journal of High Technology Management Research 10(2), 223-242.

Mention, A, S Temel and M Torkkeli (2013). Innovation and co-operation in emerging economies: Two sides of the same coin. In Proc. Int. Conf. Innovation and Entrepreneurship, in Amman, Jordania, 2013, RA Kharabsheh (ed), The Hashemite University, Amman, Jordan.

Mowery, D (2009). Plus ca change: Industrial R\&D in the third industrial revolution. Industrial and Corporate Change, 18(1), 1-50. 
Mowery, D (1983). The relationship between intrafirm and contractual forms of industrial research in American manufacturing, 1900-1940. Explorations in Economic History, 20, 351-174.

Nieto, MJ and L Santamaría (2007). The importance of diverse collaborative networks for the novelty of product innovation. Technovation, 27(6), 367-377.

OECD (2015). OECD Science, Technology and Industry Scoreboard 2015: Innovation for growth and society. Paris: OECD Publishing. http://dx.doi.org/10.1787/sti_scoreboard-2015-en.

Parida, V, M Westerberg and J Fishammar (2012). Inbound open innovation activities in high-tech SMEs: The impact on innovation performance. Journal of Small Business Management, 50(2), 283-309.

Parvan, S (2009). Quality in the Focus of Innovation. Science and Technology. Eurostat: statistics in focus 33/2009. Brussels: European Commission.

Poot, T, D Faems and W Vanhaverbeke (2009). Toward a dynamic perspective on open innovation: A longitudinal assessment of the adoption of internal and external innovation strategies in the Netherlands. International Journal of Innovation Management, 13(2), 177-200.

Raasch, C, C Herstatt and K Balka (2009). On the open design of tangible goods. $R \& D$ Management, 39(4), 382-393.

Raymond, W, P Mohnen, F Palm and S van der Loeff (2006). A classification of Dutch manufacturing based on a model of innovation. De Economist, 154(1), 85-105.

Reed, R, S Storrud-Barnes and L Jessup (2012). How open innovation affects the drivers of competitive advantage: Trading the benefits of IP creation and ownership for free invention. Management Decision, 50(1), 58-73.

Revilla, E, B Rodriguez-Prado and Z Cui (2016). A knowledge-based framework of innovation strategy: The differential effect of knowledge sources. IEE Transactions on Engineering Management, 63(4), 362-376.

Sandulli, D, J Fernandez-Menendez, A Rodriguez-Duarte and JI Lopez-Sanchez (2012). Testing the Schumpeterian hypotheses on an open innovation framework. Management Decision, 50(7), 1222-1232.

Simeth, M and J Raffo (2013). What makes companies pursue an Open Science strategy? Research Policy, 42(9), 1531-1543.

Spithoven, A, D Frantzen, B Clarysse, (eds.) (2010). Heterogeneous firm-level effects of knowledge exchanges on product innovation: Differences between dynamic and lagging product innovators. Journal of Product Innovation Management, 27(3), 363-382.

Stokes, ME, CS Davis and GG Koch (2000). Categorical Data Analysis Using the SAS System, Second Edition. Cary, NC: SAS Institute Inc.

Teece, D (1986). Profiting from technological innovation: Implications for integration, collaboration, licensing and public policy. Research Policy, 15, 285-305.

Tranekjer, T and M Knudsen (2012). The (unknown) providers to other firms new product developments: What's in it for them? Journal of Product Innovation Management, 29(6), 986-999. 
Van de Vrande, V, J de Jong, W Vanhaverbeke and M de Rochemont (2009). Open innovation in SMEs: Trends, motives and management challenges. Technovation, 29(6), 423-437.

Verganti, R and G Pisano (2008). Which kind of collaboration is right for you? Harvard Business Review, 86(12), XXX.

West, J (2006). Does appropriability enable or retard open innovation? In Open Innovation: Researching a New Paradigm, H Chesbrough, W Vanhaverbeke and J West (Eds.), pp. 285-307, Oxford: Oxford University Press.

West, J and M Bogers (2015). Leveraging external sources of innovation: A review of research on open innovation. Journal of Product Innovation Management, 31(4), 814-831.

West, J and S Gallagher (2006). Challenges of open innovation: The paradox of firm investment in open-source software. $R \& D$ Management, 36(3), 319-331.

West, J, A Salter, W Vanhaverbeke and H Chesbrough (2014). Open Innovation: The next decade. Research Policy, 43(5), 805-811. 